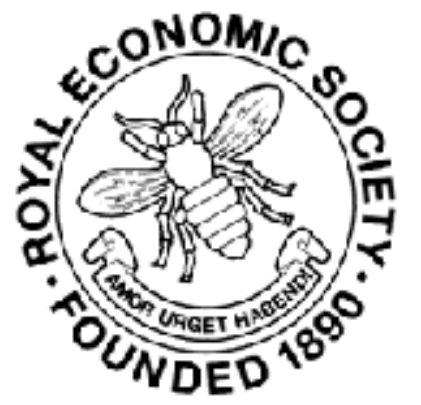

\title{
WILEY
}

The Leeds Municipal Strike

Author(s): M. E. Sadler

Source: The Economic Journal, Vol. 24, No. 93 (Mar., 1914), pp. 138-152

Published by: Wiley on behalf of the Royal Economic Society

Stable URL: http://www.jstor.org/stable/2221836

Accessed: 21-12-2015 20:15 UTC

Your use of the JSTOR archive indicates your acceptance of the Terms \& Conditions of Use, available at http://www.jstor.org/page/ info/about/policies/terms.jsp

JSTOR is a not-for-profit service that helps scholars, researchers, and students discover, use, and build upon a wide range of content in a trusted digital archive. We use information technology and tools to increase productivity and facilitate new forms of scholarship. For more information about JSTOR, please contact support@jstor.org. 
Whatever difficulties may be encountered in running this great and original system, it promises to secure general adhesion among banks of all classes at the start. Within just one month after the law was signed, 5,007 national banks, representing 75 per cent. of the capital of the system, had formally accepted the provisions of the new Act ; 169 other national banks had signified their intention of coming in, and 1,016 State banks and trust companies had asked to be included. Since this date acceptances have continued to come in rapidly, and the largest bank in the country-the National City Bank of New York-has announced its intention of joining, although its president had been one of the severest critics of the new law. Meanwhile the Organisation Committee is at work on the task of dividing the country into Reserve Districts. Before the end of 1914 it is probable that the new system will be running full blast.

Columbia University.

Wesley C. Mitchell

\section{The Leeds Municipal Strike.}

THE history of the Leeds municipal strike is well worth writing if only as a record of the series of blunders made both by the Corporation and the employees. Space will, however, not allow of any detailed account of the course of the dispute, and attention will therefore be mainly confined to some interesting and important questions which have arisen as a result of the strike.

In July, 1913, a number of municipal servants-paviors' labourers and others-obtained increases in wages amounting in the aggregate to about $£ 9,600$ a year. Almost immediately an agitation arose for an increase amongst other grades of employees on the ground that for several years a large number of municipal servants had received no rise in wages, and that in the meantime the cost of living had risen considerably. Accordingly a demand for a $2 s$. increase was formulated for workers in a number of municipal departments, the chief being the gas, sanitary, street lighting, and parks departments. The matter was discussed at the September and October meetings of the City Council, and it was decided to defer the consideration of the men's claims until after the municipal elections, it being understood that any increases granted should date back to October 1st. The threatened strike was consequently postponed by the men. At the November elections, at which the wages 
question was the main issue, the labour party gained three seats, and returned to the Council Mr. Walt Wood, the local organiser and leader of the Gasworkers and General Labourers' Unionthe chief union concerned. At the bye-elections following on the aldermanic elections, a further labour gain was obtained. The new Corporation Committees got to work and recommended certain increases for over 2,000 men (rather over one-half of all concerned) amounting to $£ 6,500$ a year. The men thereupon gave the Corporation three days in which to reconsider these concessions, and no further increases being offered, a strike was proclaimed at midnight on December 10th. Later, the tramway men came out, and after a short strike returned, with demoralising effects on the other municipal strikers. On December 31 st the men offered to resume work on conditions that the concessions made were adhered to, that men who had not received 1s. advance were granted an increase up to that amount, and that all men were reinstated. On January 7th the Emergency Committee of the City Council agreed to meet Mr. J. R. Clynes, president of the Gasworkers' Union. Negotiations were opened, and on January 13th an agreement was arrived at; advances already granted were to date from the time of restarting work, further claims for increases were to be considered on their merits, and reinstatement was to be commenced immediately and carried as far as possible. The men are no better off than they would have been if they had accepted the Corporation's offer at the beginning of December; indeed, they are worse off, as the increases conceded do not date back to October, and many men, probably about 700 , have not been reappointed.

The failure of the employees is due to a variety of causes, some of which are peculiar to municipal disputes. Generally speaking, the odds are against the men during disputes, and the odds are much greater in the case of municipal strikes. The public are the employers, and public opinion is therefore biassed. The anti-labour newspapers are a powerful weapon against the strikers. The economic issues become confused with political ideas. All these factors - the absence of a more or less independent public opinion, the attitude of the Press, and political animus-were present in the Leeds strike. The intervention of the University of Leeds, the obstinacy of the Emergency Committee of the Corporation (it is alleged that they were supported by powerful industrial interests), and the mismanagement by the men's leaders of the whole business from the beginning, completed the defeat of the employees. 
Two points call for special attention: the intervention of the University, and the attitude of the Corporation Committee. It is by no means the first time that university students have gone to the assistance of employers during a trade dispute, nor will it be the last. During the Leeds dispute, however, the matter was more serious than that. In order that the attitude of the executive officers of the University may be fully understood, it will be best to quote the words of the Vice-Chancellor, Dr. M. E. Sadler, when he received a deputation from the Leeds Trades Council on December 18th ${ }^{1}$ :-

"When, a week ago, requests for assistance reached them from certain departments of the city, a number of them-seniors and juniors-thought it their duty as citizens to give the help desired. This was no ordinary trade dispute. It was not comparable to a struggle between a private employer or a group of private employers and the working-classes. It was a determination, of which I speak with great respect, though I think it misguided, on the part of a large number of municipal employees engaged in services vital not only to the convenience, but to the health, safety, and well-being of the whole community, not least the working people and women and children ... to desist from their labour. . . . In such circumstances and in response to requests from the authorities of the city . . . some of us-senior members of the University, and students-like large numbers of other individual citizens not connected with the University at all, thought it right to take upon ourselves duties which in ordinary circumstances and in the general division of labour are delegated to others. I should like to emphasise this essential difference between the struggle which has recently taken place in Leeds and any other ordinary economic controversy. . . . In any economic conflict between the employer and his workmen in matters that do not affect the vital interests of our city or national life, none of us, as ordinary citizens, have any concern. ... We think there was put upon us, in common with all other individual citizens, the duty of using whatever skill and knowledge we possess to prevent the city from being-under, as I think, misguided counsels-held up. . . We acted ... deliberately. The city accepted our offer of help so far as that help was needed. Much more help would have been forthcoming from here if the city had required it. . . . Those of us who have been occupied in this matter have felt very deeply that in this trouble we have, in so far as our action has been efficient, rendered to that extent less effective the weapon of the strike."

The views here expressed bring out clearly two questions: first, the right to strike amongst employees in "vital services," and, secondly, the right of organised intervention by universities

1 The quotations are from the report in the Yorkshire Observer, Dec. 19th, 1913. 
during disputes in such services. The whole point of Dr. Sadler's speech is that the University, in the interests of the community, was right in giving what assistance it could against the strikers. There does not, however, seem to be any clear distinction between municipal and "ordinary" trade disputes, unless in the municipal services there can be no just ground for serious complaint, and unless there is some form of trustworthy machine for the speedy settlement of differences. There is little to show that in the matter of wages, at any rate, municipalities are deserving of special treatment at the hands of their employees. The Board of Trade Inquiry into Earnings and Hours of Labour illustrates this. The average wage in the public utility services (roads, sanitation, gas, electricity, water, and tramways) was, in 1906, 28s. 1d. per week; in the whole of the textile industries the average wage for men was exactly the same; in the clothing industries it was $30 s .2 d$. ; in building, $33 s$. ; and in the metal, engineering, and shipbuilding trades, 33s. 11d. The railways, which would be included amongst the "vital" services, paid, in 1907, 24s. $4 d$. per man on the average.

Further, "vital" services are not necessarily municipal services, for in many towns such services are in private hands. Then also the "vital" nature of industries is a matter of degree; no industry is absolutely "vital," just as no monopoly is ever perfectly complete. In both cases there are always substitutes. The nearest approach to a really "vital" service is the disposal of sewage (with which, in the Leeds dispute, the University students were not concerned). It was because the gas and electricity services were considered "vital" that the Pro-Chancellor and Vice-Chancellor of the University gave their approval to the action of the students. The active assistance given by the University officers creates a dangerous precedent. The gas supply in London, Sheffield, and Bristol, the supply of electricity at Norwich and on the Tyneside, the trams in Dublin and Oxford, are all under private, not municipal, control. If the Leeds precedent is accepted, it would be difficult for the local university officials to refuse assistance in the event of a strike in any of these services, and we should then have the university involved in "ordinary" disputes between Labour and Capital. But the category of "vital" industries is by no means confined to local services. The railways are much more "vital" than trams, and coal, obviously, than gas. The principle of intervention during disputes in "vital" services would embroil the universities of the country in every strike in industries employing over an 
eighth of all the occupied males of the country. Logically, interference in disputes in "vital" services would implicate the universities in ordinary disputes between Labour and Capital (to which Dr. Sadler objects); and if interference is limited merely to municipal strikes, then it is placing such disputes on a different footing from strikes in equally vital industries which are privately controlled-a proceeding which cannot be justified.

There is another important consideration. The trade union movement, as a whole, condemned the action of the University officers and students as an attempt at strike-breaking, and saw no reason for not stigmatising the student volunteers as "blacklegs." The implication is clearly that the intervention has not been impartial, but that the University, so far as it was able, threw itself on the side of the Corporation. Though in the speech quoted above the Vice-Chancellor considered that the strike was unwise, he refrained from passing any opinion on the points in dispute. In a communication to the Press, ${ }^{1}$ issued by the Pro-Chancellor and Vice-Chancellor, it was stated that they "took action in the belief that the failure of certain municipal services would have consequences disastrous to all classes of the community. . . . The University has not taken a side in the wage dispute which led to the strike." No one will question for a moment the motives of the University officers, but just as they were concerned with the consequences of the dispute, so the trade unionists were concerned with the consequences of the intervention of the University. The object of the strike was the suspension of certain services, and its success was dependent upon the extent to which suspension was achieved. The object in using "blackleg" labour is to maintain the services as completely as possible. The whole aim of using the services of the University students was also to maintain the municipal services, and as has already been seen above, Dr. Sadler admitted that "we have, in so far as our action has been efficient, rendered to that extent less effective the weapon of the strike." In other words, they had weakened the chances of the men's success, just as professional strike-breakers would have done. So that though there was no intention to act otherwise than impartially, the University did in point of fact aid in breaking the strike. The greatest crime in the trade union calendar is "blacklegging," and it is because the consequences of what was done by the entry of the University into the dispute were the consequences associated with "blacklegging" that the trade union movement

1 See Yorkshire Observer, Dec. 29th, 1913. 
has shown such keen resentment. On the other hand, as Dr. Sadler has pointed out, ${ }^{1}$ the University authorities did all in their power to bring about an honourable settlement of the dispute. When it is remembered that the Corporation and many powerful interests desired to avoid a conference which might lead to a settlement, this action may be regarded as taking sides with the men.

There is a further reason why universities and similar institutions should not identify themselves with labour disputes. Their intervention must necessarily be one-sided, and always against the men. However good the workers' case may be, they can take no direct action to help them. In the case of a lock-out in a "vital" industry they would not be able to maintain the service, whatever its importance to the health, safety, and convenience of the community. The maintenance of such a service is as desirable during a lock-out as during a strike, but a university would be powerless to act. In these circumstances, it would seem that, if universities are to keep themselves clear of the class war, they must of necessity refuse to maintain "vital" services during a strike.

Another complication, of a quite different kind, which added bitterness to the dispute was the refusal of the Corporation to meet the men in conference. It is difficult to realise that a large municipality in the twentieth century denied to its employees the right which is widely established in ordinary industry of conference on wages and conditions of labour. The question of increases had been before the public for a few months, and the Council decided to defer the matter until after the November elections. On the publication of the Council's concessions, the men held a mass meeting (December 7 th), at which they decided to strike in three days unless the Corporation reconsidered the position. The leader of the City Council then suggested that the whole matter should be submitted to arbitration by Sir George Askwith. The employees rejected this eleventh-hour proposal, partly because they felt that matters had gone too far for appeal to an external authority and partly because they felt that the suggestion was prompted by fear, no proposal of the kind having been made during the months the men's demands were before the Council. On December 10th the employees' leaders met the Lord Mayor, who later in the day communicated to the men the news that he had interviewed the leaders of the Liberal and Conservative parties, and that they had agreed to meet the repre-

1 In a letter to the Parliamentary Committee of the Trade Union Congress. 
sentatives of the men on the following day. December 10th saw the expiration of the three days' notice, and the men's mass meeting on that day decided that it was too late to avert a stoppage, but recorded their willingness to meet the Chairmen of Committees and the representatives of the three political parties on December 11th. This offer was ignored. Throughout the course of the strike the men's officials repeatedly asked for a conference. On December 12th a strikers' meeting called "upon the authorities to enter immediately into a conference with the men's representatives with the object of arriving at a satisfactory settlement." This attitude the men maintained throughout. Strenuous efforts were also made by outsiders to bring the contending parties together. Ultimately a "conference" was arranged, which took place on December 20th and December 22nd. On the first day the men and the Corporation met in the same room for less than an hour. The remainder of the negotiations were conducted by the exchange of typewritten statements, the two sides sitting in separate rooms. Naturally, this mode of procedure led to nothing, and negotiations were broken off. The Corporation Committee issued a statement to the effect that "the men may come back on individual application." The denial of a free and full conference and the offer of individual reinstatement strike at the roots of collective bargaining, and the question of trade union recognition became an additional issue in the dispute. On December 26th, three members of the staff of the Economics Department in Leeds University published a letter urging nine reasons for a full conference. It is clear that people were now prepared to support the idea, for two out of the three local morning papers expressed themselves favourably. ${ }^{1}$

Dec. 26th, 1913). 1913).

“ Out of such a conference much good must result (Leeds Mercury, Dec. 29th,

The comments of the Yorkshire Post (Dec. 27th, 1913) will be of interest to readers of the Economic Journal. In the course of a long article it said, "we are surprised, and somewhat disgusted, to find there are Professors in a University in receipt of public money from the ratepayers and from endowments provided by wealthy citizens who think it wrong that certain students in the University should come to the rescue of the city to whom they owe so much. We say frankly that if these Professors are sincere, and desire to be consistent, they ought to refuse any of the tainted money-that is, money provided by the ratepayers to whose primary interests they are opposed. . . . The letter which we published yesterday ... was nothing to the point. Its economics and its logic are as feeble as its citizenship. ... Are we to understand that Professor Macgregor and his colleagues in his especial branch have been trying to teach in the University the validity of Syndicalism, the right of certain leaders to plunge a great civilised community into utter darkness or starvation, and that this is what they are pleased to call the teaching of Economics 
On December 24th, a meeting of workers passed the following resolution: "That we pledge ourselves to take steps to supplement the support to the men during the present strike. Further, that we greatly regret that no proper conference has taken place during the dispute between representatives of the parties concerned, and we request the president of the Council (Mr. J. R. Clynes, M.P.) to intimate publicly our readiness to discuss immediately the points of difference with a view to an early settlement of the dispute." This decision was communicated to the Corporation Committee, which replied by asking "for any point of difference to be stated to them in writing." Further correspondence followed, and on January 7th Mr. Clynes met the committee of five. A conference was therefore ultimately achieved, although one local paper called the meetings "conversations." On January 13th terms of settlement were agreed upon, the strike having lasted five weeks. It is obvious that whilst a free discussion of points in dispute will not necessarily end immediately in agreement, yet a municipal strike cannot well be ended without a conference of some kind. It may also be laid down that under no circumstances should the representatives of a municipality refuse to meet the men. If they do refuse, their action must be considered punitive and vindictive. Proceedings in Leeds may prove to be a dangerous precedent. In Blackburn the same policy has been followed. The only hope is that some machinery may be devised which will diminish the need for resorting to the strike, and also reduce political and class animosity in municipal disputes.

\section{ARTHUR GREENWOOD}

now-a-days? If this be so, we are certain that the people in Leeds who have put their money down for the founding of chairs and the paying of salaries to these Professors will want to reconsider their attitude. ... Judging by what is reported, Mr. Macgregor seems to have believed that Economics ought to be taught from the standpoint of the Trade Unions and Syndicalists, possibly of Mr. Sidney Webb and of Mr. Henry George. We are, however, content to leave this matter to the authorities immediately concerned. We should wish to let bygones be bygones, always provided that the heads of the University exercise adequate supervision over individuals." It is also stated, regarding the real point of the letter in question, that " there can be no conference with these men."

Put into plain English all this means (1) that the people who finance Uni. versities shall control teaching so that teachers who disagree with the private views of the head of their University (and the views of the local Press) should be punished; (2) that certain views-in this case Syndicalism, etc., - should be forbidden to University teachers. A small section of political extremists in the labour movement have always viewed with suspicion any attempt to bring together the Universities and the working classes on the ground that University economists were bound to teach the views of the capitalists who provided their salaries; it is a new thing for a "Capitalist" newspaper to put forward as an ideal what these political extremists intend as a damning accusation.

No. 93.- yoL. xxIV. 


\section{Note on Mr. Greenwood's Article on the Leeds MUNICIPAL STRIKE.}

By the courtesy of the Editor and of Mr. Greenwood, I have been shown a proof of the latter's article on the Leeds Municipal Strike, and have been given an opportunity of writing a note on it. This, for reasons of time, must be shorter than a full discussion of the issues would require.

In his brief narrative of the strike, Mr. Greenwood fails, I think, to convey to the reader an adequate idea of the serious danger with which the city of Leeds was threatened at the crisis of the dispute, or of the weight of the reasons which led about a thousand of the citizens (including a hundred senior and junior members of the University) to come to the help of the city as volunteer workers, with the purpose of maintaining certain necessary public services which otherwise, to the injury and danger of the inhabitants, would have been suddenly broken.

The men's grievances first came to a head on September 21st in a demand by the Gas Workers' and General Labourers' Union for an increase of wages to the extent of two shillings a week all round, with the threat of a strike if this was not granted. On October 1st a ballot of the men confirmed this demand. But it was felt by the members of the City Council that the period immediately preceding the municipal elections was inopportune for the consideration of such a claim. A conference was therefore held by the Lord Mayor on October 14th, when the men's leaders were assured by representatives of the City Council that their application would receive prompt attention by the new committees which would be appointed after the municipal elections. On receiving this assurance, the men agreed to wait. The Council fulfilled its promise and, on December 3rd, sanctioned advances to a large number of its workmen, the total increase amounting on one calculation to about $£ 9,600$ a year. But the advance of two shillings a week all round was not conceded (a number of the employees receiving no increase at all), and the men were not satisfied with what was offered. At a mass meeting on December 7th they gave three days' notice of a general strike, unless the whole of their demand was complied with. On the following day Alderman Wilson, the Chairman of the City Finance Committee, offered, on behalf of the Council, to submit the dispute to arbitration, and suggested that Sir George Askwith should be asked to arbitrate. This suggestion was refused by the men's leaders, on the ground that there was nothing to arbitrate on, as 
they were not prepared to accept anything less than a full concession of their demand. One of the leaders said : "We contend that we can be the arbitrators:" On December 10th the Lord Mayor made yet another effort to settle the dispute. He endeavoured to arrange a conference between representatives of the Council and of the men, but the proposal to confer was rejected by the men, who adhered to their resolution to strike. Accordingly, at midnight on December 10th, the strike began, a great body of municipal workpeople withdrawing their labour at once. The number of those who came out on strike in the first instance has been variously estimated at about three or four thousand. They included workers in nearly all the city departments-in particular gas, electricity, water, sewage, and street cleaning. In the days immediately following, the ranks of the strikers were reinforced by the skilled workers of the electricity and gas departments, who left their work without giving the notice required by their contracts. The critical day was Friday, December 12th. On that day the city was threatened with the sudden and complete stoppage of its supply of both gas and electricity. Faced by this danger, the city authorities, as in duty bound, left no stone unturned in a great effort to keep these necessary services running. Help was sought wherever it might be found-from the offices of the City Council itself, from engineering and other firms, and from the general body of citizens. At the University urgent requests were received for aid in both the electricity and the gas departments. The response on the part of the citizens was immediate. In order that the streets and houses of the city might not be plunged in darkness, it was necessary to maintain in full operation the municipal electrical works and (so far as possible) the municipal gas works. The consequences of a breakdown in these services would have been very grave. There was a strong feeling amongst the citizens that the peril must be averted. A large number of citizens with knowledge of electrical machinery and gas-making appliances instantly volunteered their help. Among these were a considerable number of senior and junior members of the University. In addition to this, and likewise in response to the request of the city authorities, a very large number of other citizens volunteered for unskilled work in the gas, electricity, and other departments. This help was given without there being at the time any expectation of payment. The volunteers maintained unimpaired the supply of electrical light and power, and, after a few days of great inconvenience, entailing loss to some thousands of workpeople, the partial check in the supply of gas 
was sufficiently removed. The volunteers continued their work for about a month. Exceptional steps for the policing of the city prevented disorder, though there were three serious outrages-one of them a dangerous attempt upon a volunteer worker. The public opinion of the city was, in the main, strongly in favour of the action of the volunteers. In the ranks of the latter all classes of the community were represented. The fact that practically all the volunieers had work of their own to return to when their services were no longer needed greatly simplified the problem of reinstatement. This was recognised by the strikers as well as by the public. At the end of the dispute, when the regular workmen returned to their posts, they were intermingled for a shift or two with the volunteers. At this point there was no sign of bad feeling, but, on the contrary, more than one demonstration of goodwill on the part of the returning strikers to the volunteers who had temporarily taken their place.

There is and has been from the beginning of the dispute, so far as I am able to judge, a general desire throughout the city that all reasonable grievances on the part of the municipal employees should be removed. It is certain that the varied episodes of the strike have made the public think about the conditions of municipal employment much more seriously than before. This quickened public opinion will be an important factor in future discussions as to the wages to be paid to, and the conditions of service of, the municipal employees in the city.

Before the outbreak of the strike the leaders of the municipal employees did not conceal their belief that the withdrawal of their labour from the necessary municipal services would produce a condition of things which would compel the City Council to concede the whole of the strikers' demands. It was this implied threat, accompanied by the strikers' refusal of arbitration and of conference during the days immediately preceding the strike, that impressed the great majority of the citizens with a feeling that it was necessary to prove that, in the last resort, the vital services of the city could be carried on by volunteer effort for a time sufficiently long to defeat an attempt to bring the city authorities to their knees. With the desire of the municipal workmen to obtain an improvement in their wages, the citizens had no quarrel. They were prepared to leave proposals for the settlement of that question to those who were appointed to deal with it. They were ready to support what was judged to be fair and reasonable in settlement of the dispute. The results of arbitration would, I think, have been unreservedly 
welcomed. But when arbitration was refused by the men and an attempt made, by the suspension of necessary communal services, to force the city into surrender, the great body of the citizens felt that wrong means had been adopted by the strikers to secure what might be in themselves justifiable improvements in their condition. The action of the volunteers was not in the nature of a class struggle, but a falling-back, on the part of the city, upon its own reserves of strength for the carrying on of work which was necessary to its safety and health.

There were, in fact, three parties implicated in the struggle - the City Council quâ employer (but, unlike the private employer, subject ultimately to the ratepayers' pleasure, and including a representation of the varied opinions of the city), the municipal workmen concerned, and the community as a whole. When the relations between the City Council as employer and a large number of its workpeople had broken down, the latter (refusing arbitration and conference) took up a weapon which was turned, not so much against the City Council as employer, as against the whole community. The community, therefore, took steps to protect itself against an attempt which, if successful, would have seemed to prove that the services of a particular group of workpeople were indispensable to the continued well-being of the city. The belief that the community had not other resources of skill and strength among its own members from which to draw, and that therefore the withdrawal of the employees from the city services would force the community into compelling its representatives to concede all that the strikers asked was an illusion, and a dangerous illusion, which the experience of Leeds during December and January has done something to dispel.

A considerable part of Mr. Greenwood's article is devoted to a discussion of the part taken by members of the University in the course of these events. The University as a corporate body did not take any action in the matter at all. On Friday, December 12th, urgent requests were addressed, on behalf of the City Council, to the University authorities for help in preventing the stoppage of certain public services necessary to the health and safety of the city. In the suddenness of the emergency, the University as a corporate body could not be consulted ; but its executive officers (the Pro-Chancellor and the Vice-Chancellor, together with the Pro-Vice-Chancellor), after careful deliberation, took action, believing that the failure of certain municipal services would have consequences disastrous to all classes of the community. They communicated the request of 
the city authorities to members of the University, a considerable number of whom, seniors and juniors, volunteered immediately, like many other citizens, for skilled and other work in the gas and electrical departments of the city. What was done was directed, in the public interest, to the maintenance of the wellbeing of the city in what was regarded by its responsible authorities as a grave emergency. The University has not taken a side in the wage dispute which led to the strike. On this and other questions individual members of the University have been perfectly free to hold and express their opinions.

As Mr. Greenwood has quoted from a reply which I made to a deputation from the Leeds Trades and Labour Council on December 18th, I am sorry that he has not included in his quotation two other passages from my speech. I told the deputation that, before any members of the University undertook the duty of volunteering, I had felt it right to say two things to them. The first was that no junior member of the University should undertake the duty without the leave of his parents. In the second place, I urged upon all that they should undertake it in a very serious spirit; that they should clear their minds of any feeling of irritation or anger, and still more from any feeling of class antagonism; that they should remember they were doing for the whole community something very serious and necessary; and that they should do it quietly and without excitement, endeavouring to realise the condition of the ordinary worker's lot and determining to use their influence now and in the future for a wise and just settlement of any grievances that might exist.

At the conclusion of my speech, after admitting that, in so far as the action of the members of the University and other volunteers had been efficient, it had rendered to that extent less effective the weapon of the strike, I went on to say: "We feel that as municipal employment extends, as State employment grows, and as those monopolies which touch the essential concerns of public well-being pass under social and public control, it becomes the more necessary that all who are engaged in the charge of those monopolies should refrain from any action which, by threatening to hold up the community, might subserve their own immediate purpose. For that reason I, and I know many here, feel with great intensity the need for furnishing to the employees in the municipal and State services some right of easy appeal to a tribunal so constituted as to command general respect and armed with such powers of extensive inquiry and report as will enable it to review, and then bring before the public, whatever needs to be 
changed in the condition of employment (not wages only), with a view to their improvement by the appointed financial authority, whether in the municipality or the State."

Mr. Philip Snowden, M.P., in an admirable article published in the Leeds Mercury of January 15th under the title "Some Lessons from the Leeds Municipal Strike," urged the same point. The course adopted by my colleagues and myself, in response to the urgent request from the city authorities, seems to me to have been the best which could have been taken in the circumstances. To have refused point-blank to do anything at all, or to allow anything to be done by individual members of the University, in response to the appeal, would have been a course much less capable of justification. No pressure of any kind was put upon any member of the University to volunteer. The University as a corporate body was not involved. Those of us upon whom, as its executive officers, the immediate responsibility fell, were agreed in thinking that the community needed help, and we did not conceal our opinion that those members of the University who had the necessary skill and who wished to volunteer would, subject to their parents' consent, be right in doing so.

The facts of the case do not confirm Mr. Greenwood's fear that action taken by members of a University in a labour dispute of this kind must necessarily be one-sided and always against the men. A University is a society of men and women with freedom to express opinions formed after careful consideration of the issues involved. One of its great contributions to the life of the nation lies in the expression of considered individual judgments on questions of public importance. The support of those judgments would be of the highest value to either side in a great struggle. In the present case the action of the volunteers rendered material service to the interests of the whole community of Leeds, including the working people and their families, who would have been among the worst sufferers through a stoppage of the municipal services necessary to the well-being of the city. Mr. Greenwood adds that, "however good the workers' case may be, the Universities can take no direct action to help them. In the case of a lock-out in a 'vital' industry they would not be able to maintain the service, whatever its importance to the health, safety and convenience of the community." It is not easy to imagine the circumstances which Mr. Greenwood suggests. But if the bodies controlling a vital industry locked out all their workpeople, with cynical indifference to the interests of the whole community, the intervention of Government would be inevitable, and in that 
case, in response to the request of Government, individual citizens, including members of Universities, should be free to volunteer their help.

The University, Leeds.

M. E. SADLER

CuRrency IN 1912.

Forty-Third Annual Report of the Deputy Master of the Mint, 1912. [Cd. 6991.] 1913. Price $10 \frac{1}{2} d$.

ONE of the most interesting tables in recent issues of this Report has been that showing the amount of Imperial gold coin held by banks (including the Bank of England) in the United Kingdom on the last weekday in June each year since 1907 :-

$\begin{array}{ccc}\text { Year. } & \text { Day of the Week. } & \begin{array}{c}\text { Amount } \\ £\end{array} \\ 1907 & \text { Saturday } & 33,296,802 \\ 1908 & \text { Tuesday } & 50,369,167 \\ 1909 & \text { Wednesday } & 49,221,074 \\ 1910 & \text { Thursday } & 44,214,173 \\ 1911 & \text { Friday } & 54,009,977 \\ 1912 & \text { Saturday } & 60,640,681\end{array}$

This table is commonly studied because it is supposed to have an important bearing on the question of the gold reserves held by the banks. Some bearing on this question it no doubt has; but it is greatly obscured by a confusing and irrelevant factor. The table includes all gold coin, but not gold bullion, held in all banks, including the Bank of England. Now it is fairly safe to assume that the banks, other than the Bank of England, hold, possibly with one recent exception, no amount of gold bullion worth considering. We know also the aggregate of gold, coin and bullion together, held in the Bank of England. But there is no means of knowing in what way this holding is distributed at any given date as between coin and bullion. Thus the table would tell us approximately what we want to know, either if it told us the amount of bullion held, as well as the amount of coin, or if it excluded altogether the Bank of England's holding of coin instead of including it. The first alternative may lie rather outside what the Mint authorities regard as their proper field; but there seems little objection to the second alternative. If the table were to be republished with this correction, its scientific value would be economically increased. At present a fluctuation in the published amounts of the banks' holdings of coin may be merely due to the Bank of England's holding different proportions 